University of Nebraska - Lincoln

DigitalCommons@University of Nebraska - Lincoln

2016

Networking with Middleton and Jonson: Theater, Law, and Social Documents

Kelly Stage

Follow this and additional works at: https://digitalcommons.unl.edu/englishfacpubs

Part of the Comparative Literature Commons, English Language and Literature Commons, Modern Literature Commons, and the Reading and Language Commons

This Article is brought to you for free and open access by the English, Department of at DigitalCommons@University of Nebraska - Lincoln. It has been accepted for inclusion in Faculty Publications -Department of English by an authorized administrator of DigitalCommons@University of Nebraska - Lincoln. 


\section{KELLY STAGE}

\section{Networking with Middleton and Jonson: Theater, Law, and Social Documents ${ }^{1}$}

O, an extent, a proclamation, a summons, a recognizance, a tachment, an injunction, a writ, a seizure, a writ of 'praisement, an absolution, a quietus est.

-Tangle The Phoenix, scene $\mathrm{I} 5$, lines $3 \mathrm{IO}-\mathrm{I}^{2}$

T $\mathrm{n}$ the lines above, the lawyer Tangle seems to be listing the tools of

his trade, various legal documents he uses regularly. However, the list names more than just documents; it also labels the stream of blood trickling out of Tangle's arm as he is forced into a purgative healing. Quieto, a lawyer-cum-healer, prescribes a bloodletting because Tangle's long association with ink has infected him and the only way to cure him of poisonous legal practice is to drain him. Quieto confirms his diagnosis with the protagonist, Phoenix, who looks into the basin catching the blood and exclaims "This, why it outfrowns ink!" (I5.3I5). Having been purged, Tangle becomes quiet and feels himself restored to truth in his words and to compassion in his heart. As Quieto explains to Tangle, the joy is that "No more shalt thou in paper quarrel" (I5.328). Quieto's ritual removes the desire to go to law from Tangle's body, and thus provides a physical remedy for the tormented soul of the overzealous writer of writs. In this snapshot of Tangle, his illness, and his cure, Middleton's I6o4 play The Phoenix calls upon two readily repeated ideas in the late Elizabethan

I. I have benefitted greatly from the instruction and conversation of C.W. Brooks and the members of the Folger Institute Weekend Faculty Seminar, "The Legal and Cultural World of the Inns of Court," in April 20I2. I thank Ray Ball, John Detloff, Jeffrey Doty, Thomas Lange, Nora Martin Peterson, Joy Palacios, Meg Pearson, Amy Rodgers, and Julia Schleck for their time and sage comments, as well as two helpful readers at English Literary Renaissance.

2. All references to The Phoenix are from, Thomas Middleton: The Collected Works, gen. ed. Gary Taylor and John Lavagnino (Oxford, 2007), pp. 94-I27. 
and early Jacobean age: first, that lawyers are thieving, greedy, selfish connivers; and second, that the proliferation of paperwork involved in early seventeenth century English law was the emblem of legal corruption. ${ }^{3}$

Characters such as Tangle reflect Jacobean society's struggle to cope with an ongoing and unprecedented increase in litigation in the latter half of the sixteenth century. More credit, debt, trade, and land transfers meant more deeds, contracts, lawsuits, more practicing attorneys in London, and more men training at the Inns of Court and Chancery. ${ }^{4}$ The concentration of economic power in London furthermore meant that city law cases accounted for about twenty percent of all common law cases between I550 and I640, making legal practice a booming business in the city. 5 Legal historian Christopher Brooks explains that although the increase in the number of lawyers could have be seen as a general social good: "it is clear that most articulate men of the period did not see things this way. To them, the increase in litigation was a disaster, and the lawyers who brought the cases into the courts a group of dishonest tricksters who were a cancer on the body of the commonwealth. Allegations that attorneys stirred up unnecessary suits were accompanied by accusations that court officials were corrupt and charged extortionate fees. Such views have greatly influenced the picture of the legal profession and the legal system which has come down in the writings of modern historians."

As Brooks' summary demonstrates, the paper-pushing lawmen and their ubiquitous legal documents become the scapegoats of a newly litigious society early on, whether they deserve the distinction or not. Their presence as plot devices in early modern English plays helps document

3. For dating of the play, see Lawrence Danson's and Ivo Kamps's "Introduction" in The Collected Works, p. 9I. Edward Gieskes in Representing the Professions calls attention to this fantastic scene in The Phoenix and in general to the paper-and ink-obsessions of representations of the law in the period. Although I agree with many of Gieskes' interpretations, I am interested in calling attention to Latourian social networking theory. Gieskes' substantial and thoughtful work must be recognized here. See Gieskes, Representing the Professions: Administration, Law, and Theater in Early Modern England (Dover, 2006), especially pp. II4-6I and II4-I8 on The Phoenix.

4. The growth of the London-based trade economy and increasing centralization of the government meant that the number of suits argued at the King's Bench and the Court of Common Pleas increased roughly three-fold between I560 and I580, and six-fold compared to the beginning of the sixteenth century. The growth continued through I640, with nearly 30,000 cases in the common law courts per year. See C. W. Brooks, Pettyfoggers and Vipers of the Commonwealth: the 'Lower Branch' of the Legal Profession in Early Modern England (Cambridge, Eng., I986), pp. 57-7I.

5. Brooks, p. 66.

6. Brooks, p. I32. 
the anxiety surrounding the rising visibility of law and uncertainty over its place in everyday life. At the same time they document the tensions of a class system increasingly complicated by new status positions. Ideological concerns over the way law works and the new society that needs it, however, are often displaced on the materials and agents of law: writs, attorneys, ink. In this light, Middleton is by no means alone-as Brooks points out - in his representations of corrupt attorneys or corrupt justices. While Middleton's abstraction of lawyering as dueling with Latinate terms and spilling ink is at its metonymic height in The Phoenix, the text is following suit, so to speak, in its portrayal of the documents of law as signs of a paper pestilence and lawyers as carriers. Tangle is the very emblem of such a disease, himself infected and infecting others with his venomous writs.

In this essay, I focus primarily on Middleton's Michaelmas Term (I604I606) and Ben Jonson's The Devil is an Ass (I6I6), two plays that address law matters and use legal documents like the ones with which Tangle is associated.7 With the help of Bruno Latour's Actor-Network Theory, I examine the way the staged use of legal documents and their manipulation reveals social networks in the worlds of the plays. The dramas trace the movements of papers and people, and they allow a view of social circulation. In an abstracted, limited, fictional way they reconstruct the social space of an urban world that is otherwise intangible. Through law and its documents, they reconfigure the relationship of the virtual social world to the concrete world of city and property. The abstraction required by performance then allows the staged space to map a city of interactions-specifically London in Michaelmas Term and The Devil Is an Ass - rather than to simply name references to streets and landmarks. Instead of existing as the fading subjects of a superstructure, the characters can assert new social collectivity through their stripped down and revised version of the urban collective.

While Middleton's Michaelmas Term attempts to sweep away some of the complications of class and professional distinctions in its conservative ending, it exposes the existence (largely by omission) of a placeless professional class in the city for whom the categories of citizen tradesman and country gentleman are inadequate. Jonson's The Devil Is an Ass is a

7. For the dating of Michaelmas Term, see Theodore Leinwand, "Introduction to Michaelmas Term," The Collected Works, pp. 334-36. For The Devil Is an Ass, see Peter Happé,"Introduction," in The Devil Is an Ass (Manchester, I996), pp. I-2. 
satirical social fantasy, and one that reflects a very different conception of the "tangle" of relationships constructed around documents. Notably, the play focuses primarily on the example of the upper branch of law-an Inns of Court man is one of the play's heroes. ${ }^{8}$ It also features a cast of urban parasites who manipulate legal documents but who are not simply lower branch whipping boys like Tangle. Instead, criticism leveled at the legal system falls most heavily on the judiciary. Compared to Middleton's satirical vision, Jonson's implication that those with the power to judge do so without due consideration is far more pointed. The Devil Is an Ass's reorientation of the legal critique makes obvious the absurdity of legal manipulation, yet the power of the law and those who use their wits to use it well become fruitful in its dark satire. The lawyers, not the judges, save the play's protagonists.

In both The Phoenix and Michaelmas Term the staging of document exchange and legal interactions brings into relief the social configurations at work. In The Phoenix, attention to Tangle's networking reveals how the legal world has perverted relationships and power structures in the larger social world. The corrupted social structures in both of these plays prove to be temporary: official judgments made in the final scenes restore order and limit legal power by placing it in the hands of an overriding judging authority. Examining The Devil Is an Ass through the same Latourian lens reveals a different result: its alternative conclusion questions the ability of an authority to judge. In Jonson, the mapping of legal documents and their networks combines with the play's meta-theatricality to demonstrate that engineering social collectivity may produce new social spaces - in this case, a space opposed to the existing space of the fashionable "town."

Bringing these plays together displays the Jacobean comedy's interest in mapping the busy movements of a developing legal network in London. Documents move from hand to hand, and following them describes the lawmen's actions but also those of the ordinary citizen or

8. Early modern law in England consisted of a lower branch and an upper branch. The upper branch was primarily Inns of Court-educated and consisted of the barristers, judges, and men studying for these occupations. The lower branch were considered practitioners: attorneys and clerks who wrote writs and dealt with clients but did not appear in court before judges. They more often would have been men of the Inns of Chancery, but these definitions are not hard and fast. As Brooks explains, "The reason why the early modern lower branch was so amorphous and ill-defined is that there was in the world of procedure no such thing as an English legal system. Since there was no system, there is no simple definition of the lawyers who worked in it" (Brooks, p. I2). 
gallant who can obtain the skills needed to interpret and manipulate those documents. My discussion of agents, documents, and social spaces makes visible these elements mapping "the social" in the form of class tension, the value of wit, and the dynamics of early modern property relations. As the theater condenses and reprocesses the language of urban life and of the law, it combines the patterns of circulation from different but overlapping social collectives to rewire the urban network in favor of a new class of witty individuals using reason and interpretive skills to navigate and build their society.

\section{Networking: Plays as "The Social"}

Social networks and the idea of communal connections have become hot topics in the digital age, but we should remember that regardless of new vocabularies, social networks are hardly new. Early modern law and early modern theater are their own collectives and have many crossover connections..$^{\text {IO }}$ Both may be seen as what Latour calls actor-networks; they depend on individual connections that act upon each other, bind each other, and operate through formalized instruments to transmit

9. Peter Withington has commented on the overlapping meanings of associations, networks, and community in discussing early modern social organization. See Withington, Society in Early Modern England (Cambridge, Eng., 20IO), pp. I34-68, I7I-20I. Additionally, Alexandra Shepard and Withington's Communities in early modern England (Manchester, 2000) examines similar ideas. They offer a reorientation of the word community through the idea of the network: "The techniques of network analysis provide an alternative and complementary way of assessing social grouping and association: of correlating the skeletal, connective outlines of community across space as well as the imperatives of proximity and residence within place" (Withington and Shepherd, "Introduction" p. 7). Charles Kadushan explains that networks require only agents and information to pass. See Kadushan, Understanding Social Networks: Theories, Concepts, and Findings (Oxford, 2OI2), pp. I-42.

IO. Philip J. Finkelpearl claimed that practically all writers of reputation in the late sixteenth century were associated with the Inns of Court. Even if Inns men were not themselves writers, a large number of them were consumers of art and literature and close associates of writers and intellectuals. See Finkelpearl, John Marston of the Middle Temple: An Elizabethan Dramatist in His Social Setting (Cambridge, Mass., I969), pp. 26I-64. Lawyers and writers of drama and poetry often traveled the same circles. John Donne (Lincoln's Inn) is perhaps the most famous member of both circles. See also Michelle O'Callaghan ["Tavern Societies, the Inns of Court, and the Culture of Conviviality" in A Pleasing Sinne: Drink and Conviviality in Seventeenth-Century England, ed. Adam Smyth (Cambridge, Eng., 2004), pp. 37-5I] on the shared ground of "drinking societies" for lawyers and writers alike at taverns. See Jessica Winston on poetic commonality in the Elizabethan era: "Lyric Poetry at the early Elizabethan Inns of Court" in The Intellectual and Cultural World of the Early Modern Inns of Court, ed. Jayne Elisabeth Archer, Elizabeth Goldring, and Sarah Knight (Manchester, 2OII), pp. 223-44. 
information, money, and human emotion, among other things. Localized urban dramas necessarily flatten, constrict, and simplify the range of associations and social connections in their performances. By thinking through Latour, one can see these plays as documenting a dynamic, if fictional, network of connections and markers of sociability. That is to say, these plays are not simple reflections of London's social world or documentation showing their writers as members of social networks. Given the function of abstraction in the drama, I suggest a different move than the application of Latourian theory to the complex social world of London four hundred years after the fact. Instead, I want to examine the drama as a Latourian map documenting social networks.

Latour provides a useful toolkit for seeing and reading social interactions, even if his original focus is not the early modern world. ${ }^{\text {II }}$ In Reassembling the Social, he sets out a method of tracing "the social" from within itself rather than simply describing it from outside. In explaining what he conceives of as the actor-network (ANT), Latour offers a way to conceive of 'the social' as a product of that relationship: "The first part (the actor) reveals the narrow space in which all of the grandiose ingredients of the world begin to be hatched; the second part (the network) may explain through which vehicles, which traces, which trails, which types of information, the world is being brought inside those places and then, after having been transformed there, are being pumped back out of its narrow walls. This is why the hyphenated 'network' is not there as a surreptitious presence of the Context, but remains what connects the acts together." ${ }^{\prime 2}$ In this reading the process of mapping actors and connections together defines the structures of a society. Latour claims that the social must be reassembled from the local-from the view, as he puts it, of the ant. ${ }^{13}$ At that local level, the actor-network is a web of mediations

II. Latour himself does engage in discussions of historical developments; see e.g., his ch. six, "Centres of Calculation" on Lapérouse's expedition in Science in action: how to follow scientists and engineers through Society (Cambridge, Mass., I987), pp. 215-57. As Jonathan Gil Harris notes, Latour has even treated Shakespeare, albeit briefly, in Making Things Public: Atmospheres of Democracy. See Harris, Shakespeare and Literary Theory (Oxford, 2010), pp. 69-72.

I2. Bruno Latour, Reassembling the Social: an Introduction to Actor-Network Theory (Oxford, 2005), pp. I79-80.

I3. See Latour,pp. 9-I2 and p. I75 on the metaphoric ant in ANT. See also pp. 24-25 and pp. I6872 on cartography. In forwarding the local view and the ant metaphor, Latour objects to the idea of context, totality, and the panoramic view. His objections are similar to de Certeau's commentary on the problem of scale and panopticism. See The Practice of Everyday Life, tr. Steven Rendell (Berkeley, I984), pp.9I-96, in which de Certeau uses the experience of looking at Manhattan from the IIoth 
and attachments, between people and objects that act on each other and are in constant motion.

Latour posits that by flattening and abstracting these interconnections into simplified lines, we can see mediation as a way of collecting. Collection provides for the existence of law, politics, science, religion, and a host of other possible assemblers to exist in circulation. ${ }^{\text {I4 }}$ As such, Latour claims that ANT lets us rethink the social: "Society is not the whole "in which' everything is embedded, but what travels 'through' everything, calibrating connections and offering every entity it reaches some possibility of commensurability."'s This form of summation, although not the end of Latour's theorizing on the subject, lets us see that collectivity, social existence, and circulation are part of the process of social connection. In the act of reassembling, a collective's shape becomes, perhaps only fleetingly, visible. ${ }^{16}$

Even in the most complicated of early modern plots, plays offer a finite range of mapping and legible ways of collecting the actor ants (in Latour's sense of "actors") to define, transform, and examine "the social." Sociologists attempt to approach the field they examine objectively; Jonson and Middleton do not make that attempt, but we also cannot assume their biases or intentions. Instead, we can look at the plays as relevant data. Like Latour-inspired studies, the dramas establish, map, and propose connections between urban groups-on stage and in the audience-as they create social spaces. We need not see these maps as realistic to see them as meaningful; we can see them as what the machine of culturetheater-produces as an idea of the urban world. In tracking the "actors" of this network as defined in the plays-often lawyers but just as often those who deal with lawyers or legal issues - my analysis has an obvious starting point. The more difficult complication is to define the network. Latour proposes to look for vehicles, traces, or trails of information. Thus, rather than tracing legal rhetoric or ideology through these plays, I want

floor of the World Trade Center as an example of modernity's relentless search for the totalizing vision. For Latour's discussion of tracing connections and local information against the panoramic, especially regarding globalization, see pp. I89-90.

I4. See Latour, pp. 240-4I on this ultimate bringing into relief of the mediator and the circulation as a kind of collective.

I5. Latour, pp. 24I-42.

I6. Latour is concerned with redefining sociology and ultimately with trying to understand the possibilities for ANT's political project. Nonetheless, his theory can still be instructive for studying the past. 
to concentrate on the movements of legal documents (valid and invalid) in the plays.

The movements of documents, even as props onstage, offer the traces of social connection and intervention needed to establish social networks. If we reconsider Tangle in The Phoenix, for example, his level of connection and the breadth of his social sphere is defined by the paper that bears his ink. The character's name defines social connections in the play: a tangled web of messy associations constructed largely through legal machinations and carried out through documents (bonds, marriage agreements, wills, warrants, etc.). Tangle is so invested in his pursuit of suits that he serves as a nodal point connecting a number of diverse individuals. ${ }^{17}$ To map the social relationships in the play would show that Tangle and Falso (the corrupt Justice of the Peace) bring many of the characters into relation. Tangle works as an example of the popular perception of pernicious lawyers, but he also is a structuring device. Middleton can use the legal system to connect, through the nodes of Tangle and Falso, what might otherwise seem like diverse plotlines. The range of connections made possible by these characters' legal machinations give the disguised Phoenix the opportunity to learn the ins and outs of his city. As he explains, he goes undercover to learn more about "infectious dealings" and "foul mysteries throughout all professions" (I.IIO-II, III-I2). ${ }^{\text {I8 }}$

Phoenix guesses correctly that being in a position of power and status has cut him off from many of the sinful, greedy, and ugly practices of the people he would rule. While slumming with his man Fidelio, the heir-indisguise learns of the corruption in the system he stands to inherit. The characters' mutual conflicts, often meted out through legal actions, provide the perfect proving ground for young Phoenix. If we think merely about all the people Phoenix becomes involved with in the play through his disguise gambit, it might seem that he is truly the center of the social network and society of his dukedom. However, the documents that pass through Tangle's and Falso's hands define the relationships of nearly

I7. See Kadushan on basic terms of networking. As he explains, "A network is a set of nodes and a map showing the relationships between nodes" (p. 26). Even if Tangle is not "popular" in a conventional sense, the number of connections to others in the wider network makes him a key node in the overall network. See Kadushan, pp. 27-35 esp. on organization of networks.

I8. As Gieskes has argued, the age of early modern drama in London is characterized by Londoners discovering a new mode of "professional" life in the metropolis. The law and theater are early examples of such professionalization. See his excellent treatment of The Phoenix in the context of the growing legal professional class in Gieskes, pp.II4-2I. 
every character but Phoenix, indicating the aristocracy's estrangement from the social system it technically oversees. For example, Phoenix witnesses the Captain use Tangle and "his" scrivener to make a bond to sell the Captain's wife (Fidelio's mother) to Proditor (Phoenix's rival). In addition, Falso negotiates the will of his brother, who leaves his niece in Falso's care. He then attempts to create a legal relationship to his niece, desiring to marry her to keep her 5000 pounds for himself. We see his daughter's love interest, a knight, arrested for a debt to his tailor, which indicates another legal action mandated by document. Falso and Tangle deal with suitors and official marriage proceedings, the Justice take bribes and writes warrants, and both law men duel with each other by naming strategies to keep (or defeat) a suit in law rather than with real weapons.

While the practices of the everyday folk that Phoenix sees are ugly, it is the corruption of the legal system by way of Falso and Tangle's manipulations that literally underwrite the misdeeds of others. Tangle's productivity in creating suits, in addition to his organizational centrality, allows Middleton to unify a diverse array of characters around him. That he has so many suits in court positions the term-trotter to be everywhere at once in the city, bringing everyone's causes together. If we were to map just the movements of paper that are executed under the ruling classes' noses, we would realize that Phoenix ordinarily would be completely removed from most of the legally defined interactions that he witnesses while undercover.

The legal men are the ants, to use Latour's term, who truly structure many of the social relationships that exude the social environment of the play. They document the relationships and create the apparent structure of the social collective in so doing. Tangle's and Falso's example helps us, through thinking about the way documents mediate interactions, to consider how we trace and understand social formation. We then may realize the disjunction between the world of connections in which Phoenix usually circulates, and the world of connections that Falso and Tangle organize around the exchange of documents. Even while the play punishes Tangle and highlights his inky desires, we see that Phoenix and Fidelio learn how to use the same system for their own purposes. The final revelation of Proditor's attempts to overthrow the Duke, and his employment of the disguised Phoenix to do so, come about through the Duke's reading of a letter from Phoenix at court. The accusation against Proditor is read to him, as are all of the evils committed by Falso, the Jeweler's Wife, the corrupt nobles, and everyone else. They are all 
judged; Proditor is banished and the others punished. The play supposes that the right side wins and that law returns to the hands of the court when the duke cedes power to Phoenix by saying: "To thee then power and dukedom we resign;/He's fit to reign whose knowledge can refine" (I5.I8I-2). However, we can also think of this ritualized moment is also a rejection of social collectivity that does not directly stem from the seat of power. The play makes clear in its ending that Phoenix is in charge, first because he can navigate the tangle of social relationships created by paper and ink, and second because he replaces the corrupted, although diverse, legal network with his own aristocratic central authority from which his future relationships will extend. He does it all with a writ of his own-a letter read at court - that places the power of judgment in the hands of the ruler and relocates the center of the legal network at the court.

\section{Legal Connections: Social Networks and Paper Trails}

The Phoenix's corrupted world and its legal devices are the basis for the play's social commentary on the ills of the city and its reconciliation of urban vice and legal corruption through the imposition of a strong central authority figure (Phoenix). In Michaelmas Term, Middleton explores the way that paper documents reconfigure the relationships of city to country and of the middling sort to the nobility. However, Michaelmas Term works much more closely with the real tensions of Jacobean London, and lurking under the somewhat predictable and orderly outcome of the city comedy is a class critique that does not always levy consistent criticism. The play ends conservatively, with the gentry class reconfirmed in its wealth and status, the wealthy citizen reprimanded, and his attempts at social mobility foiled. Yet the action also indicates that the binary of citizen and country gentry is not entirely adequate. The play's London even exposes how much the binary leaves out, since the city is rife with criminals, law enforcers, officials, tradesman, and gallants. These individuals all serve as nodes-elements of the network, the play's legal and commercial machinations - but the characters are ultimately more important as vehicles for the transference of property and information than for their own social agency. ${ }^{19}$

I9. For more on actual networks of criminals in early modern London, see Paul Griffiths, "Overlapping Circles: imagining cultural communities in London, I545-1645," in Communities in 
The play traces a general pattern of legal social circulation, clarifying the relationship of the legal capital against the country-client hinterlands. The play's title and opening scene refer to the beginning of the law term of Michaelmas, also considered the start of the London "season," which was a normal pattern of London migration by the early seventeenth century. At the start of the fall term, lawyers returned to court after their summer vacations, and with them came wealthy landed gentry to do business (especially to collect rents), parliamentarians, sergeants, debtors, and an increased need for all services, food, and commodities. ${ }^{20}$ Law terms thereby changed the face of greater London, and the theater world - in particular the private companies-depended upon this influx of traffic. ${ }^{21}$ The idea of this circulation is the initial backdrop of the play, and it conjures an image of London as a hub. London connects the competing interests of the landed gentry and the lawyers, and the network extends to all those who depend upon the flow of coin into the city and the flutter of papers out to the country. We see an actor-network: the movements of the papers create virtual trails-lines mapping connections-between actors that define the dimensions of the social space. This space then does not correlate with London as a whole; it is more specific and more extensive, but cannot exist without it.

The prologue addresses the patterns of term migrations explicitly, and may likely be addressing an audience that participates in these demographic shifts. The play begins with the allegorical character Michaelmas Term who appears on stage and calls for new garments. He abandons summer country clothing and, notably, his ethical sensibilities:

Lay by my conscience,

Give me my gown, that weed is for the country,

We must be civil now, and match our evil;

Who first made civil black, he pleased the devil. (I.I.I-4) ${ }^{22}$

early modern England, ed. Withington and Shepard, pp. II5-33. On the underworld and London drama and prose, see also John Twyning, London Dispossessed: Literature and Social Space in the Early Modern City (New York, 1998); and ed. Craig Dionne and Steven Mentz Rogues and Early Modern English Culture (Ann Arbor, 2004).

20. See F. J. Fisher, "The Development of London as a Centre of Conspicuous Consumption in the Sixteenth and Seventeenth Centuries," Transactions of the Royal Historical Society xxx (I948), 37-50, esp. 42. See Francis Sheppard, London: A History (Oxford, I998), pp. I30-32.

2I. See Subha Mukherji, Law and Representation in Early Modern Drama (Cambridge, Eng., 2006), pp. I74-75 and p. I79.

22. All references for Michaelmas Term are from Thomas Middleton: The Collected Works, pp. 337$7 \mathrm{I}$. 
As Michaelmas returns to the city to do the devil's work in a black gown, we see that he enables parasitical legal London to feed on the country's resources. As he explains, the "barn is made but steward to the hall" (I2), showing the mastery in the relationship between the lawyers (Westminster Hall) and the country landowners (the barn). Middleton comes back to this idea often; in The Black Book and The Owl's Almanac, for example, he makes special consideration of the lawyer's ability to bankrupt the landowner, to trade paper writs for money, and to define the very passage of time according to his work. ${ }^{23}$

Michaelmas Term's use of the trope matches social function and geographical reality. The traffic between clients and attorneys, city and country, is defined by ink:

One day our writs, like wild fowl, fly abroad,

And then return o'er cities, towns, and hills,

With clients like dried straws between their bills;

And 'tis no few, birds to pick to build their nests,

Nor no small money that keeps drabs and feasts! (I.I.58-62)

The avian metaphor criticizes the practice of law as self-serving, but in the process traces a network of legal relationships. Writs connect clients, clerks, counselors, and judges, and they define a path of business from London out to city, town, hills, and back again. ${ }^{24}$

Such movement did shape England's and London's economic and social life cycles. In the play, this prelude provides more than topicality. First, the description marks out a network of social relationships created by writs among lawmen, clients, and city folk. It prioritizes the status of the clients first, the city folk second, and the lawmen third. The lawyers

23. In The Black Book, "delicate knaves" are blamed for manipulating language to undermine young landed gentleman as they act "with the merciless antimony of the common law" and do so by language in the use of "some crafty clause or two" (p. 2II). See Thomas Middleton, The Black Book in Collected Works, pp. 207-I8. The Owl's Almanac gives him the opportunity to describe the calendar according to the law terms. The terms are characterized by the travel of the lawyer and client from country to city, court to court. Hilary Term, e.g., is characterized by its four returns, the final of which has the client receiving "nothing but lawyers' papers" stuffing the "client's cap-case" (p. I276) which had formerly been full of money. See The Owl's Almanac, in Collected Works, pp. I274-I302.

24. Brooks clarifies how the system worked: "Writs authorized the courts to act; they were the means by which defendants were forced to appear, or alternately, the devices used to delay appearance; they could be used to take some forms of property; they moved cases from London back to the provinces for trial before the judges at assizes; and, finally, they were the medium through which the decisions of the courts were carried out." Brooks, p. II. 
serve to connect city and country, but in the prologue's reading of the situation, they have perverted the relationship of the landed gentry and the citizens. They have made those with land subservient to the whims of the city. The satire decries the practice of lawyers coming to town for the term that presumably provides much of the play's audience. It self-reflexively recognizes that the opening of the new law term highlights not just the basic relationships of lawyers to clients, but also the relationship of the theater to term-time traffic. The play must winkingly admit that it, too, desires the return of the men wearing civil black and fleecing their clients. The theater especially drains the pockets of the Inns community and therefore helps direct the flow of coin through London, consolidating rural money in urban practices.

Michaelmas further explains that he has tricked the audience with the play's title. If they expect "great quarrels in law" (I.I.7I) they will be "fondly deceived" (7I-72). His emphasis on interpretation-that the play's title "consents happily to our purpose, though perhaps faintly to the interpretation of many" (69-70) - further remarks on the obfuscation of legal argumentation, considered in this example the essence of legal practice. The prologue fashions itself as a cozener, by offering and accepting payment (six pence) for one good-Michaelmas Term, a legalthemed play - and supplying another that may not fulfill expectationsMichaelmas Term, about a scheming citizen and a naive gentleman. Of course another contradiction is inherent in this claim, as the legal language of the prologue privileges those who can parley along with Michaelmas at the same time that he lampoons them. To appreciate the trickery, one must also appreciate the language in which it is couched: the lawmen of the audience are conditioned to smile when beaten by their own kind. Later in the play, a similar tension arises when Quomodo, the play's main troublemaker, says to the audience, "Admire me, all you students at Inns of Cozenage" (2.3.485-6). The comment addresses Quomodo's own son, who has joined an Inn and thus the legal network, as well as the audience members Michaelmas Term has already mocked. When Quomodo one-ups the Inns of Court, he argues for unsettling previously argued opinions: for all Michaelmas' mocks, the citizen can very well compete with the lawyers for the title of cheat. ${ }^{25}$

25. In early modern London, the term "citizen" was used to denote men who had attained the freedom of the city, tradesmen who had achieved membership in one of the city guilds and were eligible to participate in city government. 
Most of the legal traces in the play come from the play's language and references rather than from lawyers themselves: the text is replete with legal discourse, but barely includes legal characters. ${ }^{26}$ Granted, the play's first scene offers a discussion about a lawyer. Master Salewood and Master Rearage (whose names indicate their general economic states) gossip about the death of a lawyer (Master Difficult) during the vacation leading up to Michaelmas Term. They remark that Difficult could only have died during a vacation because "he has no leisure to die in Termtime," (I.2.3I-2) and would have preferred to work even more: "He was one of those that would fain have brought in the heresy of a fifth Term" (38-39). The play depends on the idea of term-time, and as W. Nicholas Knight points out, the play's interlacing of legal language and situations speaks to the common lawyers and their enemies. ${ }^{27}$

Although the first lawyer mentioned is a dead one, there is one prominent legal man actually featured in the play. The citizen Ephestian Quomodo's son Sim has been placed at the Inns of Court (thus a member of the upper-branch), a move to help him learn social skills since he has already been classically educated at Cambridge. He does not show real desire for an education in law, but for one in manners, literature, and fellowship: the bedrock of competence in gentle society. The idea of going to the Inns to gain such an education marks Sim as the son of a city striver, although there was not as much opportunity for such advancement as it may seem. While the most important factor for membership was paying the fees, citizen sons at an Inn would have been far more the exception than the rule. The Inns' demographics reveal that only about a quarter of Inns men may have been non-noble or non-gentry in this period. ${ }^{28}$ Contemporaries viewed the Inns as a finishing school for gentry rather than a tool for social mobility; training in law was a sound idea for men

26. W. Nicholas Knight, "Sex and Law Language in Middleton's Michaelmas Terme," in "Accompaninge the players": Essays Celebrating Thomas Middleton, 1580-1980, ed. Kenneth Friedenreich (New York, I983) pp. 89-I08. See also Gail Kern Paster, "Introduction" Michaelmas Term (Manchester, 2000), pp. II-I4 and The Idea of the City in the Age of Shakespeare (Athens, I985), pp. I5I, I73.

27. Knight, pp. 89-Io8.

28. Wilfred R. Prest, The Inns of Court under Elizabeth and the Early Stuarts: 1590-1640 (London, I972), pp. 2I-24. Prest explains in reference to requirement of I604 that the Inns only admit gentlemen: "It would have been impractical and embarrassing for the benchers to have enforced the ideas, which they did not. Since status largely depended upon "port" or outward show, especially in the relatively anonymous and socially fluid environment of London, there was no urgent reason for the Inns to exclude men of bourgeois or small farmer stock whose fathers could afford to support them in the manner of gentlemen" (p. 27). 
planning to run the family estate, as Michaelmas Term makes clear. For Sim, the polishing has a different focus: Quomodo looks to climb into the landed classes. Sim's name, translated as "I would/could/might be," emphasizes the aspirational nature of his character, as well as his simplicity.

Sim's importance in the play notwithstanding, his presence is removed from the practical work of lawyering. In much of the play's main action the lawmen seem to vanish. The country gentleman comes to Town, and he is manipulated by Quomodo, who on his own uses documents and fakery to bilk the gentleman. Paper practically replaces the legal class in the play but for the exceptional presence of Quomodo's scrivener and Sim. The omission of lower branch parasites like Tangle is notable; Middleton has replaced them with the documents and sidestepped the question of class in so doing. With the connecting function of lawyers as actor-agents in the network obscured, the play appears to assert the binary of citizen wealth against gentry land.

The title's promise may not be as false as Michaelmas makes it seem, even with the problematic paucity of legal characters. As Gail Kern Paster has argued, the play's main action "concerns commercial rather than legal trickery." 29 The central storyline revolves around the woolen draper, citizen, and master cozener Quomodo's manipulations of a befuddled country gentleman new to London, Richard Easy. Easy is unfamiliar with legal language and written documents, especially bonds, and is cozened out of his land and holdings by Quomodo. While Quomodo's manipulations are in many ways commercial trickery, they are accomplished through the smoke and mirrors of seemingly legal maneuvers. The play begins with Quomodo's man gulling Easy into a debt through gambling, then having Easy make a bond to pay the debt, and involving a scrivener to write out the official forms. The debt is called in, then Quomodo arranges a fake bail for Easy to escape his apparent fate, and finally he gulls the gentleman into a new bond of "body, goods, and lands" (3.4.229). Thus, when Easy defaults, the gentleman forfeits his land to his supposed bailers (Quomodo's confederates Shortyard and Falselight) and then to Quomodo. Quomodo fakes his own death to transfer the holdings to his son Sim, and then Shortyard schemes them out from under Sim, much to his father's distress. Quomodo's legal manipulations and the circulation of written documents confirm the dangers of signing one's name to a piece of paper, especially when one does not attend to the fine print.

29. Paster, "Introduction," p. I8. 
Quomodo sets up his plot to place Easy's lands in Sim's care, and he insists that Sim would never make the same basic mistakes as Easy because of his education. Sim "will never trust his land in wax and parchment, as many gentlemen have done before him" (4. I.45-47). Interestingly, the son is not cut from the same cloth as his father the draper. He detests his father's knavery, although he attempts to keep the ill-gotten gains once they come into his hands even so. The plan still fails, as Sim does turn out to be as incompetent as he is pompous. By Act 5, when Quomodo has cozened the lands, faked his own death, and willed the holdings to Sim, the Inns man immediately loses out to the craftier manipulator, Shortyard. Sim puts Shortyard in charge of collecting his new rents, and no sooner do we see him display his mastery of paper to the audience: "Here's all the bonds, / All Easy's writings" (5.I.I2-I3). Quomodo's artful scheming to divest Easy of his lands now becomes his own agent's victory; Shortyard follows the adage that Quomodo imagines his son saying: "Men's tongues, you lie; / I'll keep by law what was got craftily" (4.4.23-24). Getting the documents could be a matter of intrigue and subterfuge, but keeping them makes the situation a matter of law.

The tracing of legal paperwork further reconfigures the relationship of country to city, or in the words of the prologue, the barn to the hall. In the new economy of bustling urban London, understanding the transference of land by deed, the importance of debt, and the shadowy work of moving around bits of parchment gives a citizen the upper hand to control commercial and legal networks. Once Quomodo gains control of the deed to Easy's land, he is able logically to collapse the categories of city and country and find a moment of ecstasy: "how the very thought of green fields puts a man into sweet inventions" (4.I.86-88)..$^{30}$ Quomodo imagines remaking himself and his spatial relationships: the citizen would become a landed country gentleman, all because of the circulation of ink on paper-even if the circulation is made possible by fraud.

While the land is Quomodo's stated obsession, he is actually interested in what the fields signify rather than their material existence. To gain the social capital associated with the land, he must use his wit and real capital (money) to transfer the real field into his hands, and then attempt to enter the gentry class. At the end of the play, the deed and the land travel

30. Matthew R. Martin, Between Theater and Philosophy: Skepticism in the Major City Comedies of Ben Jonson and Thomas Middleton (Newark Del., 200I), p. 48 on Quomodo's "Utopian vision" and sense of reconfigured social order. 
from Quomodo to his son Sim, to Shortyard, and finally back to Easy. Essex's green fields link all of these figures, but none of the "owners" leave London. The trafficking in documents shows the ease by which the circulation of deeds could seem to transform social standing, but that ultimate transformation is not yet possible. Quomodo intends for his son's position to guarantee their ascent, but he instead hijacks the system of legal transactions to insert himself into a social network in which he does not really belong. He soon finds that having the documents is only nearly as good as having a place in the gentry, and only if one can hang on to the bonds. The play is not quite ready to overthrow a system of real estate for a system of cultural capital; no one actually changes by virtue of having deeds or bonds in his hand. Even so, having a place in the network is a taste of power.

When a judge sorts out the trickery at the play's end, the action confirms the distinction between city and country and the long-standing class-defined social value of land and title. Middleton's restoration of normative expectations nonetheless requires an authority of the law-the judge, and therefore a member of the upper branch - to reset the play's moral compass. Yet the reaffirmation of law's power leaves us wondering again if the prologue's indictment of legal rapaciousness sticks. The character Michaelmas Term insists that lawyers profit on the back of the country; yet in the play, not the lawyers' but the citizens' social fantasies endanger social norms. In the final act's provision of judgment, the prologue's bitterness sweetens: law's channels to provide resolution, proper allotment, and punishment. We see law work: all one must do is follow the documents as they change hands and wait for a verdict by an ethical judge.

Like The Phoenix, Michaelmas Term reinvests its authorities with the power to sort out the documents. The judge must initially agree that although gotten in deceit, the papers held by Quomodo prove that the "lands are his" (5.3.74). Easy reveals, however, that the papers have found their way back into his own hands: Shortyard gives the papers back when Easy presents the rogue to real officers, who take him and Falselight away. Thus the system seems ultimately to work as the judge confirms Shortyard's shortcomings, explaining "Craft once discovered shows her abject line" (5.3.89). As Edward Gieskes argues, the play reveals that law is a tool, and its practitioners must supply morality for it to function properly. ${ }^{3 \mathrm{I}}$ The judge takes punishment seriously, and in the last lines

3I. See Gieskes, p.I5I. 
of the play banishes Shortyard and Quomodo's other right-hand man, Falselight. They have deceived the law and have been arrested, but that the judge merely declares Quomodo to be his own tormentor stands out as comparatively light punishment. Although we assume Falselight and Shortyard are both frequent offenders, the distribution of justice seems even and generally set against those who are primarily instruments (Shortyard and Falso) rather than instigators (Quomodo). The punishment implies that these lowlier elements are disposable, and exposes a need to keep citizens working away in the city, no matter how corrupt.

Michaelmas Term's "ordinary" events explore the dangers of a society underwritten by bond. In remedying these dangers, the play partially rejects the fantasy of social mobility - the citizen is left odd man out, the lower tricksters banished-and offers instead the fantasy of justice that is appropriate, conclusive, and speedy. For all of the prologue's bravado about law's ills, Middleton offers members of different social networks different ways to read the play. For the gallants, it is merely another citizen comedy, in which the old master gets his comeuppance. For the lawyers, the tradesman's desire to manipulate law and his failures makes fun of those who attempt to enter the "new" professional network without adequate training. The manipulation and criticism of urban officials such as sergeants and bailiffs, and the sneaky right-hand men of Quomodo, offer satire ripe for the enjoyment of apprentices and journeymen. For the citizens, the example of Sim offers a new generation crossing over from "citizen" to "professional" as a possibility. However, the play favors tradition in regard to upper branch status, and Sim's presence and unaccountability suggest that a figure who can transform cultural capital into real capital has not yet been fully realized. Sim is not crafty enough to be a citizen and not smart enough to be a lawyer, so he fails, and the last statement made about him in the play is that Quomodo intends to disinherit him. In Michaelmas Term, there is no place for someone in-between: everyone must return to his respective community or be banished.

Michaelmas Term and The Phoenix both are useful for explaining the apparent prejudices of the non-lawyer against the lawyer, the perceived differences between the two branches of the law, and the perceived relationship of London to the rest of the country. These plays map the busy movements of a developed legal network in London and the essential fact that it exists through the traces of paper documents as much as it does through the existence of visible agents. The plays also register class tensions but reaffirm notions of dynastic power structures and 
traditional forms of status. Michaelmas Term hints that the system has new cracks, and is vulnerable to crafty manipulation, but cannot fully imagine a character who smoothly and skillfully may navigate a network that connects traditional groupings of citizens and gentlemen. If we follow Latour's directive to analyze the social world as indicated by the traces of the network - documentary evidence and legal practice-we see that it cannot sustain the machinations of men like Quomodo and create a working alternative to the static status system. These plays in the end snap back to the pre-comedy status quo, reforming lawyers and citizens to create order from the top down through their confidence in a wise authority figure, even if his judgment may not be entirely fair. The analyses I have offered, however, only begin to reveal the way in which theater and law are shaping each other's social spaces. To do this more fully, we will need to consider a play that much more explicitly meshes the circulation of legal documents with awareness of stage space, theatrical practice, and the figuration of urban space.

IV

\section{Reshaping the Network: Legal Spaces and Theater Spaces}

The Devil is an Ass differs from Michaelmas Term or The Phoenix in that the play's values are aligned with the interests of the legal audience. ${ }^{32}$ Most importantly, the play holds up an Inns of Court man (Eustace Manly) and his gallant friend (Wittipol) as its heroes and explicitly stages Lincoln's Inn (albeit through a window). It condemns a greedy and profligate country gentleman who opposes Manly and Wittipol. The action refutes the corrupt justices of the peace and affirms the wisdom of common lawyers. As a whole, the play provides a morality tale in which the devil cannot compete with the hell wrought by the denizens of London, and it satirizes the strictly fashionable, empty-headed urban characters. The action is complex and I must narrow my focus to consider the characters' agile manipulations of legal documents, performance, and urban space. The play's relationship with the audience emphasizes connectivity because the metatheatrical elements emphasize the power of having competency to interpret legal documents and playtexts, the need for rational behavior in the face of materialistic excess, and the potential

32. All references from The Devil Is an Ass are from Ben Jonson, The Devil Is an Ass, ed. Peter Happé (Manchester, I996). 
of performance to create social opportunities. The end of the play affirms the social power invested in the legal system and even in legal documents; in so doing, the play challenges class structures and appointed authority and posits that the social world surrounding Jonson's crafty legal manipulators is produced by the operations of wit, learning, and interpretive skill.

The trail of legal documents and transactions that form the backbone of the play's action outlines the network of relationships producing urban and legal spaces. The play makes clear that London in general is not a place that is easy to navigate or to tolerate: the initial scenes present a devil (Pug) determined to bring more evil into the city. He is informed that this will be a challenge, but allowed to try anyway. Pug's initial sweeping tour of the city by the devil Iniquity functions, as Peter Happé writes, "to show London as the scene of a moral struggle, the result of which is always in doubt."'33 In Iniquity's description of London's immoral landscape, Jonson inserts the typical idea of the predatory legal network in the devil's observation of lawyerly perambulation:

to the Strand down to fall

'Gainst the lawyers come dabbled from Westminster Hall,

And mark how they cling with their clients together,

Like ivy to oak, so velvet to leather (I.I.73-76).

The image of lawyers entwining themselves about their clients introduces two important ideas: first, that the description charts out the in-between zone often identified as the Town, between Westminster Hall and the City; second, it provides a conventionally negative view of lawyers, against which we must consider the rest of the play.

Jonson's point of view on the "victim" of legal trickery in the play, Fabian Fitzdottrel, is not sympathetic. His failure to negotiate legal traps convinces the audience of his stupidity rather than of the immorality of legal manipulators setting traps. Fitzdottrel is a profligate country squire come to London and the antagonist of the piece. Yet he is also the center of various networks operating in the play. Fitzdottrel's ignorance points to the same social problem as Easy's gullibility: the need for the country gentry to be properly educated. A country gentleman who does not understand how to make legal, land, and social transactions cannot survive in London. The play additionally suggests that perhaps he should not.

33. Happé, p. I2. 
By comparison, Easy may not be fully competent, but he is the victim of fraud as much as of his own credulity.

Fitzdottrel's missteps are frequent. Merecraft and Everill, a pair of London projectors, trick him into thinking he can become a Duke by engaging in a fens-draining project on his lands. They trick him again into thinking that he must file official forms in order to challenge Wittipol (the town gallant) to a duel for humiliating him, and in the course of negotiating the first document he ends up with a document that will divest him of his estate. He is obsessed with the occult, and yet does not recognize that he has hired a devil for a butler. He wants to spend his time at the theater, but he does not know how to act at a play, nor does he know how to detect when others are "playing" him. He keeps his very intelligent wife under lock and key, and then attempts to send her to an academy led by the most vapid women in London. In that pursuit, he becomes infatuated with a woman who is actually a man. Clearly, without the social education of an institution like the Inns of Court and without the proper friends, a country gentleman is unprepared for life in in London. As Leah Marcus puts it, the Fitzdottrels are part of "a gentry out of place." 34 Fabian's admission that his social training was at an academy, where he learned to "make my legs and do my postures" (2.8.22) exposes his shallowness and his complete misunderstanding of what skills he requires. His lack of knowledge becomes clear in his mismanagement of his and his wife's land and money.

The country squire's careless ways and underestimation of his wife's personal and monetary value lead to the play's primary conflict between him and Wittipol. Wittipol desires to protect Frances, and perhaps to do more, which leads him to antagonize Fitzdottrel. As in many urban comedies, the female love interest in the play is a piece of property to claim. Yet the lover's pursuit calls upon the lady to function as an intelligent, pure, and most importantly, rational human being. While the conflict over Frances shows each man trying to incorporate her into his own web of social associations, Fitzdottrel treats her as property and Wittipol's motives shift. In Wittipol's meetings with Frances, she proves herself to be rational and intelligent, and he recognizes her winning qualities. She privileges rational behavior when, worried about what her coming to meet Wittipol might mean, she asks that he remember her state even if

34. Leah S. Marcus, The Politics of Mirth: Jonson, Herrick, Milton, Marvell, and the Defense of Old Holiday Pastimes (Chicago, 1989), p. 86. 
her actions do not look "like reason" (2.6.57), and asks for him to excuse her. Wittipol insists instead that he had hoped to have left her in a state of "all reason" (2.6.62). While his motives are not pure, the conversation offers an expectation that she should act in her own person, with her own faculties.

The ways the two men try to possess and to use Frances as the play proceeds mark how they circulate in social, legal, and theatrical networks. The scene above renders the manipulation of social connections over stage space, legal space, and private space that reveals the construction and destruction of social networks. In this scene and the one following (2.6 and 7), Wittipol and Frances talk through two upper floor windows. He leans out his friend Eustace Manly's chamber in Lincoln's Inn, reaching out to Frances at her gallery window in the Fitzdottrel home. The interchange would have been possible to stage in the Blackfriars Theater by positioning the two actors in the theater's upper gallery, either in side boxes across the stage from each other, or on opposing sides of the main gallery. The two thus meet in thin air, a narrow region between a legal space (Manly's Lincoln's Inn chamber) and a domestic space (France's gallery). Their relationship is charged with eroticism, and certainly some potentially heavy petting on Wittipol's part, and defines the meeting of these two realms. For Frances, the exchange is her practical entry into the urban world; having been kept in the house, despite its location in the heart of the town and next to Lincoln's Inn, she has not yet circulated in the city. When she leans out her window, she crosses into a new space and connects to Wittipol. She becomes a node bridging the legal network of Lincoln's Inn, the urban network of Wittipol's associations, and her gallery's private space.

This moment is charged by potential negative readings of Frances, which show the risk she takes by appearing for Wittipol at all. As Lena Cowen Orlin has shown, for a woman to show herself in a window could signify looseness or prostitution. Even if the window was positioned to look onto a courtyard or not directly onto the street, the female standing in a window opens herself to questions of respectability. ${ }^{35}$ The issue also becomes one of privacy: as Orlin puts it, "Windows look through walls,"36 and as Adam Zucker comments, windows in Tudor and Stuart dramas often become "a figurative locus for men's fears about

35. Lena Cowen Orlin, "Women on the Threshold," Shakespeare Studies 25 (I997), 50-58.

36. Lena Cowen Orlin, 54. 
the penetrability of the walls of their homes and the bodies of their wives and daughters." ${ }^{37}$ That she is in her gallery also reminds the audience that the window frames Frances as a work of art, an idea that Lisa Hopkins explores in Middleton's Women Beware Women. ${ }^{38}$ Wittipol may see her as both the work of art he has elevated aesthetically and the loose lady he wishes she were. Following Orlin's and Hopkins' arguments, when Frances approaches and makes obvious the threshold of the window, she brings into relief a liminal space between private domesticity and public commercial life. For his part, Wittipol too breaks a barrier, opening Manly's closed walls of law to the same public urban space, but does not risk his reputation as Frances does.

The connection, and Frances' existence as a new nexus point, is fleeting. Fitzdottrel's reappearance draws her back from the liminal space, and the boundary between private and public snaps back into place. The squire catches Wittipol wooing his wife, and he appears behind Frances at her window to confront the gallant. He forcibly removes Frances from Wittipol's reach, bringing her back into his control, a response that confirms the cultural taboos applicable to women in windows and aligns Fitzdottrel with jealous husbands in other plays. ${ }^{39}$ Even so, the squire's verbal incompetence prevents him from operating as an intellectual equal to Wittipol and appearing likable in the scene. While the two exchange words, Wittipol accuses Fitzdottrel of being an ass, to which the squire manages to insist, "I am resolved on't sir" (2.7.I3). His failed verbal sparring causes Fitzdottrel to take out his anger on a target he can reach, Frances (2.7.I6). He attempts to use her as a vehicle, connecting his anger to Wittipol by hurting the element they have in common. By closing her off from the world again, Fitzdottrel disconnects Frances from Wittipol and disrupts the network. Having failed to create a lasting network through these direct means, Wittipol will ultimately use the tools of legal

37. See Adam Zucker, The Places of Wit in Early Modern English Comedy (Cambridge Eng., 20II) p. I22.

38. See Lisa Hopkins, "Art and Nature in Women Beware Women," Renaissance Forum I (I996), I2 par. Web. Oct I, 20I4. See Paragraph 5 especially.

39. Orlin points out the paranoia of women at the window in Women Beware Women, The Merchant of Venice, Volpone, and The Broken Heart. See Orlin, 54-55. She notes that all of her examples come from plays in an Italian setting, but argues that the English audience would have the same cultural reactions. Jonson here uses the motif in an explicitly English backdrop, and the same problems of reputation are implied. Zucker also makes the Italian connection, but echoes the same sentiments on men's jealousy and the conventionality of the gendered reading of the window. See Zucker, p. I22. 
documents - the feoffment designating Fitzdottrel's lands - to realign social relationships otherwise limited by conventional social mores.

The play revolves around the ways that competing interests attempt to get their hands on Fitzdottrel's land and his wife, and on Fitzdottrel's concerns about the way his wife can be used (for or against him) in establishing his place in Town society. The men trying to undo Fitzdottrel will use the key tools of legal manipulation and theatrical performance against him. Fitzdottrel, caught in the middle, never exactly understands the networks buzzing around him and merely focuses on improving his visibility in the vapid social sphere of the Town.

Despite affecting an admiration for theater, Fitzdottrel's failure to understand society's dependence on pure performance leads him to be credulous in his dealings with conmen and socialites alike. Believing that Frances' behavior will be viewed negatively and that she is the only thing preventing him from gaining the proper friends and place in Town life, Fitzdottrel relies on the advice of the conmen to improve his wife and thus his connections. While the scene between Wittipol and Frances offers a (mostly) private meeting designed to create a new social bond, the play offers two public meetings in which the tools of theatrical performance and legal manipulations are equally necessary for success. These scenes present the ugliness of surface spectacle and the emptiness of a social space constructed by empty performances. The comparison of illusory theatrical and social performances with real, substantive legal actions makes the revelation possible and adds to the play's argument for privileging reason and skill.

The first scene of public display brings the central charactersFitzdottrel, Frances, Wittipol, Merecraft, Everill, Manly, Lady Tailbush, and Pug - into social connection. The incident follows the episode with Wittipol, when Fitzdottrel's failed challenge and his belief that he must correct Frances' behavior in order to ascend in the Town's social world spur him to drastic action. While Merecraft and Everill are busy conning Fizdottrel into believing he can become the "Duke of Drowned Lands," they offer Fitzdottrel two solutions. First, they convince him that he must file official paperwork, including a dependence and a feoffment, to have his challenge taken seriously. Second, they promise to help him place Frances at the academy for wives because they have connections with a highly respected "Spanish Lady" about town. These deceptions set up Fitzdottrel for mistakes that culminate in disaster at a gathering held by Lady Tailbush. 
These two strategies to "help" Fitzdottrel are dependent on quasi-legal maneuvering. The projectors convince Fitzdottrel to formalize his dueling challenge addressed to Wittipol by filing a dependence, a document which is not actually necessary. Merecraft then leads Fitzdottrel to believe that he must "settle his estate" (3.3.I34) in order to be taken seriously (thus proving he is willing to die in the duel), and convinces the squire to have a deed for his land drawn up. Fitzdottrel is so impressed by Merecraft's apparent ease in explaining the business of making a feoffment that he fully trusts his advice on the legal transaction. Yet, as Barbara Kreps explains, the feoffment Fitzdottrel has drawn up is not the best instrument for settling an estate- a will would do-and so he walks directly into a legal trap since it can be used to transfer his land while he is still alive. $4^{\circ}$

The second part of the strategy involves the skilled theatrical performance of Wittipol and allows him to take over Merecraft's and Everill's plan to his own benefit. With the feoffment in hand, Fitzdottrel approaches the Spanish Lady at a gathering held by Lady Tailbush, a fashionable lady and con artist in her own right. Fitzdottrel hopes to curry favor with the Spanish Lady and is to offer her a ring in exchange for her help getting Frances into the academy. The situation is entirely false, as Merecraft and Everill ask Wittipol to play the part of the Lady and to help them fleece Fitzdottrel of the ring in the process. While Fitzdottrel focuses on the Lady, Merecraft and Everill both attempt to convince the squire to make one of them his feoffee.

The scene demonstrates the value of carefully integrated document manipulation and theatrical performance. Unbeknownst to the sharks, Wittipol has his own motivations for helping the men with their plan. Among the fashionable Town ladies, the gallant plays the part of the Spanish Lady and practically seduces Fitzdottrel. Under his spell, the squire gives him the ring and "she" manipulates him into making Manly the feoffee. They thereby steal Fitzdottrel's land and snatch it from Merecraft's and Everill's sweaty palms. Furthermore, Wittipol and Manly leave the gathering having stolen Frances' allegiance. The manipulation of the feoffment would not have been possible had Wittipol's performance been lacking or if Fitzdottrel has been a better interpreter of theater. Despite knowing that to be fashionable he must attend playsFitzdottrel early in the play states that he has been at Blackfriars to watch

40. Barbara Kreps, "Contract and Property Law in The Devil Is an Ass," The Ben Jonson Journal 8 (200I), 85-I22, IO3 especially. 
The Devil is an Ass - the squire does not understand how to watch a play. Manly and Frances see through Wittipol's performance and guess his intentions. Fitzdottrel has no clue and is equally lacking in introspection regarding the legal documents he signs. In contrast, Wittipol shows he knows how to integrate these skills and the networks in which he works to produce an interesting result. He explodes the status quo, and in so doing constructs a new, small, preferential network out of those present at the gathering: himself, Manly, and Frances.

Jonson delights in the self-reflexivity of Wittipol's role-playing, pointing out the nesting layers of performance as a necessary part of everyday life. As James Mardock writes, the play is "about citizens appropriating theatricality for their own purposes." ${ }^{11}$ When the conmen come to Wittipol to play the Spanish Lady, they have already found that popular actor Dick Robinson was not available to play the part. ${ }^{42}$ The audience in the know has received a special wink from Jonson, since Robinson likely played the part of Wittipol. The play goes beyond the self-awareness of Michaelmas Term's prologue, this time embedding the practice of theatergoing as an essential skill for making good society. The Spanish Lady as played by Wittipol goes above and beyond his/her script, however. "She" does con Fitzdottrel, and "she" exposes Lady Tailbush's obsession with empty fashionablity and the vapidity of the academies. That Tailbush desires someday to be one of the "examples o'the town, and govern it" (4.2.I4) emphasizes that the competing social networks-Manly and Wittipol's against Tailbush and the projectors (Merecraft and Everill)are looking to define a little piece of greater London for themselves. The display of Town manners confirms even for Pug that these fashionable people are entirely undesirable: as he says, "Hell is / a grammar school to this" (4.4.170-7I). Wittipol's demonstration separates the networks and demonstrates that to avoid living in hell, one must not be duped by the Lady's collective and Town manners.

In London, academies like the one in the play certified connections in social networks defined by performed status. In the play, the academy's role is recognized but also criticized. The gathering of admirers around Lady Tailbush and her supposed academy of wives crystalizes the wits' understanding of, and eventually disgust with, Town life. As Janette

4I. James Mardock, Our Scene is London:Ben Jonson's City and the Space of the Author (New York, 2008), p. II3.

42. Happé, The Devil is an Ass, n.2.4.64, p.I28. 
Dillon describes the Town, it was "a world of shopping, display, and spectatorship"43 defined by cultural practices of display rather than by official boundaries. To be a citizen, for example, required meeting stipulations of the guild structure in London proper, and guaranteed one of certain privileges and representational status in the City of London. The Town is a social space produced through the social practices of self-performance and social circulation rather than by jurisdictions, governance, and strict physical boundaries. Jonson's example of the academy-an early one here, as Jean Howard notes - and his lambasting of the Tailbush contingent, serves as pointed criticism of such overt and yet empty performances of status. ${ }^{44}$

The play's final scene brings us another space of combined theatrical, legal, and city intrigue. With it is another chance to consider the process and consequences of observing dramatic performance. Through performance, Fitzdottrel, with Merecraft's and Everill's help, attempts to reassert his control over legal documents, his estate, and his wife. He tries to nullify the feoffment by accusing Frances, Wittipol, and Manly of sorcery and by performing his own demonic possession to prove the accusation. Fitzdottrel puts on quite a scene: he foams at the mouth, speaks in multiple foreign languages, rants and raves, and inflates a fake stomach to prove he is under the devil's control. Like The Phoenix and Michaelmas Term, the final verdict in the play requires formal judgment, and a Justice of the Peace, Sir Paul Eitherside, provides just that. The feoffment held by Manly is at stake, much as the deeds in Michaelmas Term are. Since there has been no miraculous return of the paper to the rightful owner as in the previous play, theatrical performance alone serves to counter the facts, and the justice must determine the truth. Critics have argued that the J.P.'s quick decision that Fitzdottrel is possessed implies the incompetence of a contemporary judge although which one is unclear. ${ }^{45}$ More

43. Janette Dillon, Theatre, Court, and City, 1595-1610: Drama and Social Space in London (Cambridge, Eng., 2000), p. I25.

44. Jean E. Howard, Theater of a City: The Places of London Comedy, 1598-1642 (Philadelphia, 2007), pp. I84-86. Academies were far more prevalent in Caroline drama and the I620s and I630s in general.

45. For example, Sir Edward Coke (under fire after the Cockayne Project's failure), Justice Winch, Sergeant Crew (both disgraced in the Overbury scandal, which also reflected poorly on Coke), and former Chief Justice Popham (who had interrogated Jonson after Poetaster premiered and who had been involved in various fens-draining projects) have all been suggested as possible analogues. See Robert C. Evans, "Contemporary Contexts of Jonson's The Devil Is an Ass" Comparative Drama, 26 (1992), I40-76; especially 79-86 on Coke. See Marcus, pp. 89-92 on Winch and 
to the point, the criticism focuses on a judge's duty: Eitherside's lack of interpretive skills underscores his failure in juridical procedure. Jonson's criticism of legal London targets those in authority and favors the lawyer in this case, the figure considered pernicious in the other examples I have explored.

Manly registers outrage that Eitherside ignores proper procedure. Sir Paul insists that his "conscience" (5.8.IOI) will decide the case, but the Lincoln's Inn man argues for process:

What grave dotage moves you to take part

With so much villainy? We are not afraid

Either of law or trial; let us be

Examined what our ends were, what the means,

To work by; and possibility of those means.

Do not conclude against us ere you hear us. (5.8.92-97)

The application of legal procedure- "law or trial"-emphasizes the machinery of justice. Manly does not dispute Eitherside's authority, but simply insists that their case deserves to be heard. Paul is not convinced by an argument for procedure and does not allow their testimony. The scene shows that those in power will abuse it and that the draw of a spectacle can cloud the judgment of those who are explicitly entrusted to be judges. The true hellish inequity of London turns out to be the willful dismissal of inconvenient rules. The play argues that the structure of the legal system, and even its bureaucracy, must maintain its integrity for there to be justice.

The play gives us a moment to consider the value of documents, performances, and interpretations in creating different social worlds. In his discussion of the violence of legal interpretation, the legal theorist Robert M. Cover considers the real consequences of the word of judgment. Though Cover writes from a contemporary American standpoint, many of his considerations on the power of an individual judge's voice can still apply to The Devil Is an Ass. Eitherside's incompetent rendering of judgment without process is not just about our heroes; it encapsulates what Cover calls "social practices of violence" when he condemns people based on his interpretation of events. ${ }^{46}$ As Cover points out, legal interpretation is supposed to be different from literary interpretation

Crew, and Julie Sanders, "A Parody of Lord Chief Justice Popham in The Devil Is an Ass" Notes and Queries, 44 (1997), 528-30 on Popham.

46. Robert M. Cover, "Violence and the Word" Yale Law Journal, 95 (I985-I986), I60I. 
(and other forms of interpretation) because legal judgment metes out collective action of society through an authority figure. He explains, "It will not do to insist on the violence of strong poetry, and strong poets. Even the violence of weak judges is utterly real-a naive but immediate reality, in need of no interpretation, no critic to reveal it." 47 This proves to be exactly the problem for the heroes of Jonson's play. What should be an interpretation of art-Fitzdottrel's impersonation of one possessed-has become an interpretation rendering a judgment capable of providing real effects.

Jonson thus points out the violence of judgment and the danger of not knowing how to distinguish between art and reality. Moreover, he shows it twice. In the first rendering, when Fitzdottrel falls into Wittipol's trap, he is in fact divested of his lands. Real effects take place, but Fitzdottrel's choice to sign the feoffment is his own. He commits himself to his own undoing. The judge's poor decision will condemn the heroes to the fate of social violence. The play's condemnation of Paul attacks the minor judiciary and praises the monarch, calling to mind King James's intervention in a I6I6 trial that sentenced six women to execution based on a false possession deemed by a lower judge to be true. ${ }^{48}$ The example illustrates that the vehicle, the play, does not do violence in the real world by exposing such poor interpretation of the social world it has created. Instead, it alerts the audience to the ways they may see or fail to see justice in the real world.

Tense moments follow as the comedy looks to condemn its heroes. Ultimately, the news of a devil-sighting at Newgate prison-Pug happily returning to Hell—causes Fitzdottrel to break character and expose his ruse, saving Manly, Frances, and Wittipol. The diabolus ex machina lets Manly's voice of reason have the final say on moral justice, and he shames Sir Paul and Fitzdottrel. He testifies to Frances' virtue and asserts that Fitzdottrel's "land is his" (5.8.163). Exactly how this is so remains unclear; either Manly surrenders the deed gained in 4.7, or the transfer was not complete without a formal livery of seisen. ${ }^{49}$ The flux between the

47. Cover, p. I609.

48. Anthony Parr, "Introduction," The Devil Is Ass, in The Cambridge Edition of the Works of Ben Jonson, ed. David Bevington, et al (Cambridge, Eng., 20I2), p. 470 and pp. 467-76. See also Marcus, p. 9 I.

49. Kreps notes that the play shows Fitzdottrel's apparent divestment, but offers a confusing scenario. The inclusion of a letter of livery and seisen with the feoffment would require that the seisen be carried out at the estate itself, preventing total transference. Kreps, pp. II2-I3. 
written document and the formal actions of law allows room to wiggle: in Act Four, we may cheer that Fitzdottrel has signed his estate away. In Act Five, we may believe that shaming Fitzdottrel is an equitable solution and that Manly can astutely settle the legal matters. The ending seems to acknowledge that even a legally literate audience may have lost track of the documents and the procedures at hand, and we must accept Manley's solution. He acts with the authority of the judge in this moment, and we accept his interpretation of the situation and the documents as Eitherside does.

The language of Manly's pronouncement imbues words with action; as Cover explains, "The judicial word is a mandate for the deeds of others. [...] Thus, the institutional context ties the language act of practical understanding to the physical acts of others in a predictable, though not logically necessary, way. These interpretations, then, are not only "practical," they are, themselves, practices." 50 The documents in the play thereby trace out the real social force of legal work; however, only sometimes are the documents' meanings appropriately and finally interpreted, bringing about action. In this case, Manly can undo the violence formerly threatened by Fitzdottrel and Eitherside, wipe out any hopes of Merecraft and Everill, and place Frances and Wittipol in better situations. The failure to interpret correctly the performances of Pug, Wittipol, and Fitzdottrel could have resulted in real danger had Paul's decision stood. When the skill of literary interpretation and legal interpretation come together, the vanities and devilries of London may be defeated.

The social fantasy of the ending affirms the collection of everyone into the same network. Jonson's last scene insists on the importance of law over folly, earth over Hell, and justice over urban and legal corruption. Yet without the devil's exit, Manly, Wittipol, and Frances could not have defeated Fitzdottrel. The comic catastrophe offers a chance for a more equitable urban life, made possible only by the devil's horrors at the hell of staying in the Town and his hasty exit. Jonson's construction of a new social collective evidences the work that the theater, its practitioners, and its audiences can do to understand their mutual connections and to define their own social networks. Necessarily, he privileges his audience: critical theatergoers and well-educated legal men are the architects of an urban space that can undo the inequities of vapid fashion, country dullards, and corrupt officials. Inns men make theatergoing

50. Cover, p. I6II. 
a part of their social practice; that dramatist and writers associate with them gives performance, representation, and social construction mutual ground on which to build an experimental urban world. ${ }^{\text {II }}$ It is a place, like the Town, in which social practices can still define a social world. By undercutting the vapid practices of Tailbush and her network, and controlling Fitzdottrel's obsession with land and money, the collectivity of a new society shows discretion and interpretation as the practice of a physical and social space between city and country.

$\mathrm{V}$

\section{Conclusion}

We see a different kind of awareness of social life if we examine the way the jostling of the actor-network shakes out ideas of urban reform, stabilization, or change. This is a society underwritten by lawyers' ink, but the playtexts are as important as the legal writs. J.H. Baker attempts to define the Inns of Court's substantial influence on culture, explaining that: "perhaps that influence, in a cultural as well as a technical sense, even extended to the ninety per cent of members who were not lawyers, the knights of the shire and the Justice Shallows of Clement's Inn, whose everyday lives would inevitably be governed by parchment and wax and legal terminology." ${ }^{2}$ However, the Justice Shallows, the Michaelmas Terms, and the Manlys map out ways to see the possibilities for change in everyday life. Baker's pithy trio of "parchment, wax, and legal terminology" all have real effects in the real world. In the period I603-I6I6, the virtual idea of relationships also cannot be, as Quomodo well knows, stripped entirely from the associations of real estate. Real estate's value and possession, however, can be shaped by legal documents and their manipulation. As a result, London's relationship to the rest of England and given social

5I. We know that some of the earliest records for plays performed at the private theaters come from the diaries of Inns men working and studying in London. In general, the private theaters in and near the fledgling west end, like Paul's, Blackfriars, and Whitefriars reputedly enjoyed the business of Inns of Court men as a great part of their audience. See Mukherji, on audience (p. I79). See also Charles Whitney, Early Responses to Renaissance Drama (Cambridge, Eng., 2006), esp. pp. I23-32. An impressive list of theater writers is also associated with the Inns: John Marston, Francis Meres, Ben Jonson, Thomas Lodge, George Chapman, Thomas Middleton, John Webster, Francis Beaumont, John Ford, and James Shirley. On shared legal-literary membership, see Brian Corrigan, Playhouse Law in Shakespeare's World (Cranbury, NJ, 2004), pp. 37-47.

52. J. H. Baker, "The third university I450-I550; law school or finishing school?," in The Intellectual and Cultural World of the Early Modern Inns of Court, pp. 8-24, esp. p. 2 I. 
collectives' relationships to city space become inscribed in legal networks. Tracking documents, the networks they connect, and the wit used to manipulate networks, allows us to see the vacuity of the system and that wit can become as valuable as wealth.

Refining social relations to the scope of a performance allows the play to show its own worth to the audience. The audience may develop an understanding of the job of interpretation, for example, but the play demonstrates a way that individuals dealing with agents, not with outside forces, define the shape of their world. As Anthony Parr has claimed about Jonson's play, "insofar as The Devil Is an Ass envisages the possibility of reform, it locates it not in royal fiat but in the newly found capacity of some of his characters to change and grow." ${ }_{3}^{3}$ In comparison to The Phoenix and Michaelmas Term, The Devil Is an Ass presents a significant shift in sensibility. There is no solution from the top to be found in Jonson's early modern metropolis; the play documents instead the way that the audience may understand social forces, the importance of observation, and the skills of a witty interpreter of law, of theater, and of the social map sketched in the play.

The city comedies I discuss are not just interested in lawyers or in law, but in the way that savvy city folk are able to manipulate their social connections-mapped for us through legal instruments-for their own greedy benefit. The implications of such manipulations are potentially far-reaching for the social hierarchy and for defining the social practices that an individual must understand in the constantly evolving social world of greater London. Michaelmas Term allows for the transference of real property, status, and wealth through the manipulation of legal documents (some fraudulent) and social connections. Citizens strive against the gentry, and legal power is the only way to right the social fantasies that endanger social norms-even if the play initially seems to revile the practices and policies of law and lawyers. In Middleton, these machinations can recognize but not fully reshape a status system that is growing inadequate. The binaries of citizen and gentry as well as country and city, are challenged but the values of wit and guile are ultimately trumped by procedure and top-down hierarchy. For Jonson, the playtext and performance offers a moment to consider who and how the world comes into social connection. The Devil Is an Ass opens a new social space when the authority of judgment is challenged. The play allows for

53. Parr, p. 476. 
an alternative investment in a legal agent and his interpretative expertise rather than shutting down new social exchanges. Following Latour lets us examine the way playtexts and performances work as social maps: they offer a sense of how a network comes together and how its manipulation can reorganize relationships, and by extension, the world defined by those relationships. The constructive power of everyday practices becomes apparent, and the need to see and interpret those social practices becomes all the more necessary for an individual.

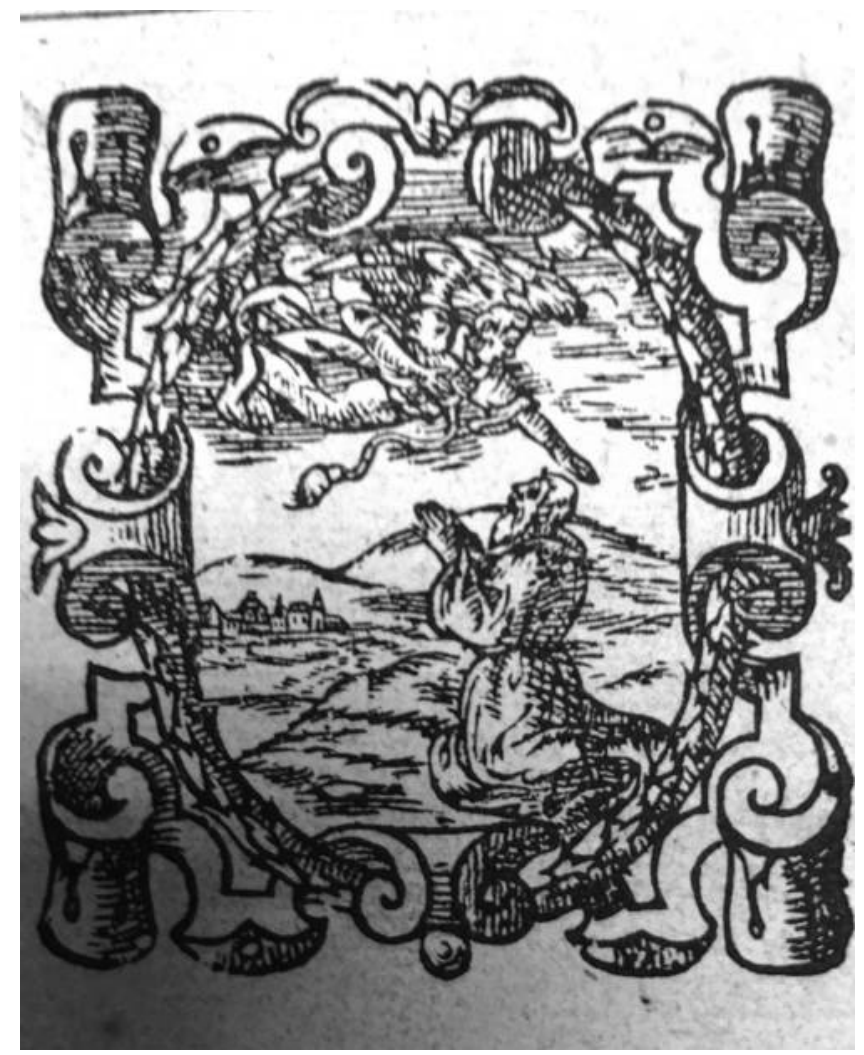

